\title{
PENCEGAHAN KEKERASAN SEKSUAL PADA ANAK DENGAN MEDIA KOMIK DI WILAYAH KERJA PUSKESMAS MAJASEM KOTA CIREBON
}

\author{
Rinela Padmawati*1, Dewi Vimala ${ }^{1}$ \\ ${ }^{1}$ Poltekkes Kemenkes Tasikmalaya, Indonesia \\ *e-mail: padmawatirinela@yahoo.co.id ${ }^{1}$
}

\begin{abstract}
Children if they get abusive treatment from others tend not to know how to refuse. Especially if they get sexually abused they feel they don't understand that they have been sexually abused. This phenomenon occurs because children do not really understand that the body must be protected from violence, including sexual violence. They only understand that their parents must protect their bodies. Whereas the perpetrators of sexual violence against children according to the records of the Indonesian Child Protection Commission are the closest people to children, such as stepparents, biological relatives, and friends. Therefore it is necessary to provide knowledge on how to protect their own bodies from sexual violence. Community service activities are carried out as a way to provide knowledge to maintain sexual violence against children through comic media (illustrated stories) given to elementary school children in Class 2. Knowledge is assessed from the increase in pre-test and post-test scores given to students. The result is an increase in student knowledge after reading the comic with the title "I am My Body Protector". It is hoped that this comic giving activity can be given to all elementary schools in Cirebon.
\end{abstract}

Keywords:comic, sexual violence,reproductif health

\begin{abstract}
ABSTRAK
Anak-anak bila mendapatkan perlakuan kasar dari orang lain cenderung tidak mengetahui bagaimana cara menolak. Apalagi bila mendapatkan perlakuan kasar secara seksual mereka merasa tidak memahami sudah diperlakukan kekerasan secara seksual. Fenomena tersebut terjadi karena anakanak tidak begitu memahami bahwa tubuh harus dilindungi dari kekerasan termasuk kekerasan seksual. Mereka hanya memahami bahwa yang harus menjaga tubuhnya adalah orang tuanya. Padahal pelaku kekerasan seksual pada anak menurut catatan KPAI adalah orang terdekat anak, seperti ayah tiri dan kandung, keluarga terdekat, dan temannya. Oleh sebab itu diperlukan pemberian pengetahuan bagaimana cara menjaga tubuhnya sendiri dari kekerasan seksual. Kegiatan pengabdian kepada masyarakat dilakukan sebagai salah satu cara memberikan pengetahuan untuk menjaga kekerasan seksual pada anak dengan melalui media komik (cerita bergambar) yang diberikan pada anak Sekolah
\end{abstract}

56 | Edukasi Masyarakat Sehat Sejahtera (EMaSS) : Jurnal Pengabdian kepada Masyarakat Volume 2 No.1 Tahun 2020 
Dasar Kelas 2. Pengetahuan dinilai dari peningkatan nilai pre tes dan post tes yang diberikan pada siswa. Hasilnya ada peningkatan pengetahuan siswa setelah membaca komik dengan judul "Aku Pelindung Tubuhku”. Harapannya kegiatan pemberian komik ini dapat diberikan ke semua Sekolah Dasar di Kota Cirebon

Kata kunci: komik, kekerasan seksual anak, kesehatan reproduksi

\section{PENDAHULUAN}

Perlakuan kasar banyak terjadi pada orang yang terlihat lemah, salah satunya pada anak-anak. Tindakan tersebut akan menjadi trauma baik fisik maupun psikologis. Sehingga memerlukan pemulihan yang sangat lama dan membutuhkan biaya dan tenaga. Apabila terjadi pada anak-anak akan menimbulkan masalah yang sangat kompleks. Selain fisik dan psikologis, kehidupan sosial anak pun akan terganggu sehingga akan menghambat pertumbuhan dan perkembangan anak. Pendidikan anak juga akan terganggu sehingga masa depan anak banyak mengalami gangguan. Menurut KPAI kasus kekerasan seksual pada anak dari tahun 2016 ke 2017 mengalami penurunan. Namun kasus kekerasan seksual yang terjadi pada anak-anak masih terjadi. Mungkin saja kasus yang terdata merupakan kasus yang dilaporkan, bagaimana bila ada kasus kekerasan seksual pada anak yang tidak terlaporkan karena masyarakat kurang memahami bahwa anak tersebut sudah mengalami suatu kekerasan seksual oleh keluarga terdekat.

Metode yang dilakukan oleh lembaga peduli anak untuk memberikan pengetahuan tentang kekerasan seksual dan cara menjaga diri dari kekerasan seksual sudah banyak dilakukan. Tidak hanya lembaga peduli anak, lembaga lain yang peduli terhadap anak pun sudah melakukan kegiatan untuk mencegah terjadinya kekerasan seksual pada anak. Pemerintah pun sudah melakukan pencegahan kekerasan pada anak terutama kekerasan seksual dengan cara memasukkan pengetahuan tentang kesehatan reproduksi kedalam kurikulum sekolah.

Cara lain untuk memberikan pengetahuan tenatng menjaga diri dari kekerasan seksual pada anak adalah dengan memberikan bacaan yang menarik seperti komik atau cerita bergambar. Metode ini dilakukan salah satunya adalah mengikuti program Sekolah Dasar yaitu program literasi. Dengan mengikuti program literasi ini media komik diharapkan dapat membantu meningkatkan pengetahuan anak tentang menjaga diri dari kekerasan seksual. Media komik ini sudah dilakukan penelitian di salah satu sekolah dasar dan hasilnya media komik dapat meningkatkan pengetahuan lebih tinggi dibandingkan dengan media lainnya.

57 | Edukasi Masyarakat Sehat Sejahtera (EMaSS) : Jurnal Pengabdian kepada Masyarakat Volume 2 No.1 Tahun 2020 


\section{METODE}

Metode yang dilaksanakan adalah memberikan komik pada anak-anak dengan judul "Aku Pelindung Tubuhku" untuk dibaca bersama-sama. Pengetahuan anak tentang tubuh dan cara menghindari kekerasan seksual dilihat dari peningkatan nilai sebelum membaca komik dan setelah membaca komik tersebut.

\section{HASIL DAN PEMBAHASAN}

Pengabdian kepada masyarakat adalah usaha untuk menyebarluaskan ilmu pengetahuan, teknologi, dan seni kepada masyarakat.Kegiatan tersebut harus mampu memberikan suatu nilai tambah bagi masyarakat, baik dalam kegiatan ekonomi, kebijakan, dan perubahan perilaku (sosial). Pengabdian masyarakat ini berdampak pada pengetahuan anak untuk mengetahui wawasan tentang tubuh dan cara menghindari kekerasan seksual pada anak.

Pengabdian masyarakat ini melakukan pemberian informasi dengan menggunakan media komik hasil dari penelitian yang berjudul "Aku Pelindung Tubuhku" yang diberikan pada naka kelas 2 SD di SDN 2 Majasem Kota Cirebon. Kegiatan ini dilakaukan untuk meningkatkan pengetahuan anak agar terhindar dari kekerasan seksual di lingkungannya. Kegiatan dapat dilaksanakan dengan baik dan lancar walaupun saat membaca komik bersama ada beberapa anak yang masih harus dibacakan sebagian karena belum bisa membaca dengan lancar. Selain itu selama kegiatan berlangsung harus bisa mengendalikan tingkah laku anak-anak, oleh sebab itu pada saat pelaksanaan kegiatan dibantu oleh guru pendamping kelas. Komik ini dapat diterima oleh anak-anak terlihat dengan antusias mereka membaca sampai akhir cerita. Hasil kegiatan dapat dilihat di tabel dibawah ini :

Tabel 1. Karakteristik anak kelas 2 di SDN 2 Majasem Kota Cirebon

\begin{tabular}{|c|c|c|}
\hline Karakteristik & Jumlah & $\%$ \\
\hline \multicolumn{3}{|l|}{ Jenis Kelamin } \\
\hline Laki-laki & 12 & 31 \\
\hline Perempuan & 27 & 69 \\
\hline \multicolumn{3}{|l|}{ Usia } \\
\hline 6 thn & 1 & 3 \\
\hline 7 thn & 18 & 46 \\
\hline 8 thn & 19 & 49 \\
\hline 9 thn & 1 & 3 \\
\hline
\end{tabular}

58 Edukasi Masyarakat Sehat Sejahtera (EMaSS) : Jurnal Pengabdian kepada Masyarakat Volume 2 No.1 Tahun 2020 
Mayoritas anak berjenis kelamin perempuan 69\% (27 orang) dan berada di rentang usia 7-8 tahun.

Tabel 2. Pengetahuan anak kelas 2 di SDN 2 Majasem Kota Cirebon

\begin{tabular}{lccc}
\hline \multicolumn{1}{c}{ Pengetahuan } & Rata-rata & min & $\max$ \\
\hline Pre Test & 51 & 42 & 68 \\
Post Test & 89 & 47 & 100 \\
\hline
\end{tabular}

Pengetahuan tentang tubuh dan menghindari kekerasan seksual pada anak rata-rata nilainya 51 dengan nilai paling rendah 42 dan paling tinggi 68, dan pengetahuan setelah diberikan komik mempunyai rata-rata 89 dengan nilai paling rendah 47 dan paling tinggi 100.

\section{SIMPULAN}

1. Terdapat peningkatan pengetahuan tentang tubuhku dan cara menjaga diri dari kekerasan seksual dengan melihat hasil pre tes dan post tes

2. Siswa senang membaca komik dengan judul "Aku Pelindung Tubuhku"

3. Pengetahuan kesehatan reproduksi dapat diberikan kepada siswa Sekolah Dasar dengan cara memasukkan dalam kurikulum sekolah atau dengan cara pemberian pengetahuan melalui media.

4. Komik dengan judul "Aku Pelindung Tubuku" dapat diberikan kepada semua siswa Sekolah Dasar untuk memberikan pengetahuan tentang menjaga tubuh dari kekerasan seksual.

\section{UCAPAN TERIMA KASIH}

Penulis mengucapkan terima kasih kepada Kepala Puskesmas Majasem Kota Cirebon, Kepala Sekolah Dasar Negeri 2 Majasem Kota Cirebon, guru pendamping, dan Poltekkes Kemenkes Tasikmalaya yang telah membantu dan memberi dukungan terhadap pengabdian ini. 


\section{DAFTAR PUSTAKA}

Hety, D.(2017). Pengetahuan orang tua tentang pendidikan seks dini pada anak usia pra sekolah (3-6 tahun)di TK Tunas Jaya Bangsa Mojokerto. Hospital Majapahit.

Machfoedz, I., Suryani, E., Sutrisno \& Santosa, S.(2005). Pendidikan Kesehatan Bagian Dari Promosi Kesehatan. Yogyakarta: Fitramaya.

Notoatmojo, S. (2010). Ilmu Perilaku Kesehatan. Jakarta: Rineka Cipta

Noviana PI.(2015). Kekerasan seksual terhadap anak: dampak dan penanganannya. Sosio Inf [Internet]. Hal 1(1):13-28. Available from: http://ejournal.kemsos.go.id/index.php/Sosioinforma/article/download/87/55

Paramastri,I.,J.E.Prawitasari,Yayi,S.P.,Endang, \& Ekowarni. (2011). Buklet sebagai Media Pencegahan terhadap Kekerasan Seksual pada Anak-anak. Jurnal Kesehatan Masyarakat Nasional.6:77-84

Pemerintah Republik Indonesia.(2002). Undang-Undang Republik Indonesia Nomor 23 Tahun 2002 Tentang Perlindungan Anak. Undang Republik Indones [Internet]. Available from: http://www.kinerja.or.id/pdf/86547a83-b8d6-461f-afae-f16f968fae8e.pdf

Ridha A, Azwar F. (2016). Efektivitas Media Komik Pada Pengetahuan Dan Sikap Mengenai Cuci Tangan Pada Siswa Sekolah Dasar. Vol 5(1):1-7.

Suliha, U., Herawani, Sumiati \& Resnayati, Y. (2002). Pendidikan Kesehatan Dalam Keperawatan. Jakarta: EGC.

Zulaikha, S. (2012). Efektivitas Pendidikan Gizi Dengan Media Booklet Terhadap Pengetahuan Gizi Anak SD. Jurnal KesehatanMasayarakat.7:121-128

60 Edukasi Masyarakat Sehat Sejahtera (EMaSS) : Jurnal Pengabdian kepada Masyarakat Volume 2 No.1 Tahun 2020 